\title{
Howard Jackson (ed.): The Bloomsbury companion to lexicography
}

\author{
London: Bloomsbury, 2013, 420 p. ISBN: 978-1-4411-4597-0
}

\author{
Vincent B. Y. Ooi
}

Published online: 26 June 2014

(C) Springer Berlin Heidelberg 2014

In his extensive editorial introduction to this volume of 20 chapters written by leading experts in Lexicography, Howard Jackson does not shy away from the discussion on whether lexicography draws primarily on linguistics, or whether it is inter-disciplinary in outlook. The term 'lexicography' is preferred to 'lexicology' for a wider inclusion beyond linguistics. Lexicography has been advocated as an 'independent discipline', a branch of reference science or even information science. Therefore, dictionary research can include many aspects and activities: history, typology, compilation, structure, content, pedagogy, users' expectations, reference skills and e-lexicography. From this perspective, The Bloomsbury Companion to Lexicography is aimed 'primarily at students of lexicography who are proposing to undertake research in one of the areas covered by [the term lexicography]'.

Broadly, there are eight sections that are ordered as follows: (1) Introduction (by Howard Jackson); (2) A History of Research in Lexicography (by Paul Bogaards), (3) Research Methods and Problems; (4) Current Research and Issues, (5) New Directions in Lexicography, (6) Resources (by Reinhard Hartmann), (7) A Glossary of Lexicographic Terms (by Barbara Ann Kipfer), and (8) An Annotated Bibliography (by Howard Jackson). After Jackson's introduction, the next chapter provides a historical overview and a general evaluation on research in lexicography by the late Paul Bogaards. Bogaards concludes the chapter with the excellent observation that 'research in lexicography does not constitute one consistent body. It is more of a patchwork composed of quite separate domains... this is due to the absence of a comprehensive theory, but up to now it is unclear how such a theory should, or even could be formulated.' Bogaards' observation is borne out in this volume, with no fewer than ten chapters on the theme of Current Research and

\footnotetext{
V. B. Y. Ooi $(\bowtie)$

National University of Singapore, Singapore, Singapore

e-mail: vinceooi@nus.edu.sg
} 
Issues, three chapters on New Directions in Lexicography, and three chapters on Research Methods and Problems in Lexicography.

In the section on 'Research Methods and Problems', the student can learn from Lars Trap-Jensen on researching lexicographical practice, Kaoru Akasu on methods in dictionary criticism, and Hilary Nesi on researching users and uses of dictionaries.

In the largest section on 'Current Research and Uses', the student can get an upto-date view on the following: (a) using corpora as data sources for dictionaries, and the value of 'word sketches' (by Adam Kilgarriff), (b) electronic dictionaries and search techniques (by Verónica Pastor and Amparo Alcina), (c) researching historical lexicography and etymology (by John Considine), (d) issues in pedagogical lexicography, with special reference to the Monolingual Learner's Dictionary (MLD) for Advanced Learners of English (by Amy Chi), (e) a comparison of leading English monolingual learners' dictionaries (by Shigeru Yamada), (f) an appreciation of issues in compiling bilingual dictionaries, with exemplifications from Russian, Polish and German dictionaries (by Arleta Adamska-Salaciak), (g) learning how to compile dictionaries for African Languages (by Danie J. Prinsloo), (h) an illuminating chapter, replete with visual illustrations, on issues in sign language lexicography (by Inge Zwitserlood, Jette Hedegaard Kristoffersen and Thomas Troelsgård), (i) identifying, ordering and defining senses (by Robert Lew), and (j) a chapter that addresses 'the methodological and notional issues encountered in discussions of theories of lexicography' (by Tadeusz Piotrowski).

Under 'New Directions in Lexicography', Pedro A. Fuertes-Olivera analyses some challenges that lexicography faces in the Internet era, illustrating particularly from his own Accounting Dictionaries. Charlotte Brewer reflects on the future of historical dictionaries and provides an update on the Oxford English Dictionary (up to 2012). Finally, Sandro Nielsen offers a general gaze into the future of the dictionary by postulating dictionaries as 'digital assistants'.

This volume complements other works that detail practical methods of inspecting concordances and other related lexical information (e.g. Scott and Tribble 2006), and those that research lexis from the perspective of (various) linguistic theories (e.g. Hanks 2008). Students researching lexicography will invariably have to grapple with the notion of triangulation and could benefit from a chapter that considers the corroboration and possible conflict between different types of linguistic/lexicographic evidence. For instance, Meyer and Nelson (2006) could be adapted for evaluating the proportion (or otherwise) of various types of linguistic evidence: personal intuitions, citational, conventional corpus, social media (such as Twitter and Facebook) and even Google/Yahoo. In this volume, there is a general predominance of English and other European languages and not much focus on Asian dictionaries and languages (apart from the helpful reference to Asialex) for a consideration of methodological and theoretical issues in lexicography. Extending Humblé (2010), it would certainly be good for future volumes to include dictionaries that cover Asian languages such as Chinese, Japanese, Indonesian, Vietnamese and Tagalog [in this regard, Humblé (2010) erroneously claims that analyses of Chinese dictionaries are not found in Ooi et al. (2009)]. Equally, Indian 
and Austronesian languages should not be neglected. With reference to e-lexicography and the Internet, students researching lexicography would also want to know helpful criteria for evaluating the evenness of the content and coverage of various online dictionaries (see Ooi 2010). Akasu's chapter, although largely considering print dictionaries, may be useful in this regard; Fuertes-Olivera's chapter on e-lexicography is useful for detailing the processes and challenges involved in applying new technology to lexicography.

Overall, The Bloomsbury Companion to Lexicography will certainly prove to be a much stimulating resource for students undertaking research in lexicography. The volume has an immense wealth of information and state-of-the-art summaries by leading teachers and researchers. I would certainly recommend it to students who take my module on Lexicology and Lexicography.

\section{References}

Hanks, Patrick (ed.). 2008. Lexicology: critical concepts. Abington: Routledge.

Humblé, Philippe. 2010. Review of Vincent B.Y.Ooi, Anne Pakir, Ismail Talib, Peter Tan (eds.) Perspectives in Lexicography: Asia and beyond. International Journal of Lexicography, 23(3):366-371.

Meyer, Charles F., and Gerald Nelson. 2006. Data collection. In Handbook of English linguistics, ed. Bas Aarts, and April McMahon, 93-113. London: Blackwell.

Ooi, Vincent B. Y. 2010. English Internet lexicography and online dictionaries, in Lexicographica 26. Berlin: de Gruyter, pp 143-154.

Ooi, Vincent B.Y., Anne Pakir, Ismail S. Talib, and Peter K.W. Tan, eds. 2009. Perspectives in Lexicography: Asia and beyond. Tel Aviv: K Dictionaries.

Scott, Mike, and Chris Tribble. 2006. Textual patterns: Key words and corpus analysis in Language education. Amsterdam: John Benjamins. 